\title{
EFFECTS OF INORGANIC PHOSPHORUS FRACTIONS UNDER DIFFERENT TILLAGE PRACTICES ON WHEAT (Triticum aestivum) IN AN ACID SOIL OF WEST BENGAL (INDIA)
}

\author{
K Mandal and D Mukhopadhyay* \\ Department of Soil Science and Agricultural Chemistry, Uttar Banga Krishi Viswavidylaya, Pundi- \\ bari, Cooch Behar (India)
}

Accepted: $27^{\text {th }}$ September 2016

\begin{abstract}
Phosphorus (P) is an essential element for plant growth and is usually applied to soil as inorganic $P$ fertilizer. An experiment was conducted to study the effect of inorganic phosphorus fractions and tillage operations (conventional and zero tillage) on the yield of the crop. The field experiment was laid out in a randomized block design with nine treatments replicated three times. Recommended dose (RD) of fertilizer (kg/ha) of N:P:K (a) 100:60:40 (RD) was modified in different treatments as ; $T_{1}$ (untreated control), $T_{2}$ (NP as $\left.R D\right), T_{3}$ (K+P as $R D), T_{4}\left(N K\right.$ as RD $+P$ as $25 \%$ of RD)], $T_{5}$ [NK as RD and $P$ as $50 \%$ of $\left.R D\right], T_{6}$ [NK as RD and $P$ as $75 \%$ of RD; $T_{7}$ [NKP as RD], $T_{8}$ [NK as RD and $P$ as125\% of RD ] and $T_{9}$ [NK as RD and $P$ as $150 \%$ of $R D$ ] . Surface soils were collected (0-20 cm depth) from each plot and important soil properties were studied. The soil was acidic in reaction having pH- 5.6 and EC of $0.06 \mathrm{dSm}^{-1}$. The available $\mathrm{N}-\mathrm{P}-\mathrm{K}$ in soil was $126.34 \mathrm{~kg} / \mathrm{ha}, 20.13 \mathrm{~kg} / \mathrm{ha}$ and 133.28 $\mathrm{kg} / \mathrm{ha}$ respectively. The inorganic forms of phosphorus (Ca-P, Al-P, Fe-P, Re-P), in soils during the experimental period showed higher fractions in the conventional tillage than the zero tillage operation. The Al-P fraction of soil affected significantly $(\mathrm{P}=\mathbf{0 . 0 5})$ towards the yield of the crop (wheat) compared to other $P$-fractions.
\end{abstract}

Key words: Acid soil, Phosphorus fractions, Tillage, Wheat

\section{INTRODUCTION}

Wheat (Triticum aestivum) is the world's most important cereal crop after maize and rice, in terms of both area cultivated (232 million ha) and amount of grain produced (595 million $\mathrm{t}$ ). Wheat has a high demand for phosphorus and can grow well when phosphorus is not supplemented in the fertilizer schedule, may be due to the wheat's ability to mine phosphorus from the soil. Phosphorus $(\mathrm{P})$ is an essential element for plant growth and is applied in soil as the inorganic and/or organic $\mathrm{P}$ and is critical for the sustainability of cropping systems. Slaton et al. (2002) reported that in acidic soils, the soil $\mathrm{P}$ is bound in compounds, such as Fe and Al phosphates, which are essentially insoluble under aerobic or upland conditions. Transformation of different forms of phosphorus (P) control the soil $\mathrm{P}$ and the processes are strongly influenced by temperature, moisture, plant growth, root activity as well as by organic matter status of the soil. Therefore, infor-

*Corresponding author: dibsm107@gmail.com mation on various soil $\mathrm{P}$ fractions is needed for better understanding on soil $\mathrm{P}$ transformation processes and $\mathrm{P}$ availability to plants. The soils of Cooch Behar district of West Bengal (India) are acidic in reaction and the distribution of inorganic $\mathrm{P}$ in the surface soil is sporadic. The transformation of added $P$ in different insoluble forms and their availability in soil depends upon the properties of the soil and sources of $P$. Hence, the low availability of $\mathrm{P}$ in acid soils may not be due to their low inherent available $\mathrm{P}$ status, but also might be due to the forms of $\mathrm{P}$ compounds that are inert and insoluble under specific conditions. Among the insoluble inorganic phosphorus compounds, $\mathrm{Fe}$ and $\mathrm{Al}$ are main binding agents in acid soils. Tarafdar et al. (2006) reported the less available P (0.3-0.9 \% of total $\mathrm{P})$ in acid soils. Although, much work has been done on growth and yield of wheat under various phosphorus levels, but the actual cause of better growth of wheat due to variations of phosphorus levels and fate of the added fertilizer in soils is not clearly under- 
stood. The experiment was undertaken to study the inorganic phosphorus fractions in soil under different tillage operations on wheat and its reflection on yield of the crop.

\section{MATERIALS AND METHODS}

The investigation was carried out during the Rabi season of 2012-13 and 2013-14 on wheat (Cv. K0307) in an acid soil of Cooch Behar district of West Bengal (India). The different phosphorus fractions (Aluminium - P, Iron-P, Reductant soluble-P, Calcium bound $\mathrm{P}$ ) in soils were estimated by the standard methodologies (Black,1965, Peterson and Corey, 1966). The field experiment was laid out in a randomized block design with nine treatments replicated three times. The different treatments as $T_{1}$ (untreated control), $\mathrm{T}_{2}$ (NP as $\left.\mathrm{RD}\right), \mathrm{T}_{3}(\mathrm{~K}+\mathrm{P}$ as $\mathrm{RD}), \mathrm{T}_{4}(\mathrm{NK}$ as $\mathrm{RD}+\mathrm{P}$ as $\left.25 \% \mathrm{RD})\right], \mathrm{T}_{5}[\mathrm{NK}$ as $\mathrm{RD}$ and $\mathrm{P}$ as $50 \%$ of $\mathrm{RD}], \mathrm{T}_{6}[\mathrm{NK}$ as $\mathrm{RD}$ and $\mathrm{P}$ as $75 \%$ of $\mathrm{RD} ; \mathrm{T}_{7}[\mathrm{NKP}$ as $\mathrm{RD}], \mathrm{T}_{8}[\mathrm{NK}$ as $\mathrm{RD}$ and $\mathrm{P}$ as $125 \%$ of $\mathrm{RD}]$ and $\mathrm{T}_{9}[\mathrm{NK}$ as $\mathrm{RD}$ and $\mathrm{P}$ as $150 \%$ of $\mathrm{RD}$ ] were applied on wheat $(\mathrm{Cv} . \mathrm{K} 0307)$ under the tillage operations as Zero tillage (ZT) and Conventional tillage (CT). The sources of N-P-K were urea, single super phosphate and muriate of potash respectively. Soil samples were collected from the plots at CRI (Crown Root Initiation), flowering and harvesting stage of wheat. The yield of crop was estimated under the two systems of tillage operations to correlate the same with the different phosphorus fractions. The statistical analysis was done by the Indostat software.

\section{RESULTS AND DISCUSSION}

The collected soil samples $(0-20 \mathrm{~cm}$ depth) were acidic $(\mathrm{pH}-5.6)$ in reaction (Table 1) having the low organic carbon content $(0.40$ $\%)$ and EC $\left(0.06 \mathrm{dSm}^{-1}\right)$. The available N-P-K ranged from $126.34,20.13$, and $133.28 \mathrm{~kg} \mathrm{ha}^{-1}$ respectively. The soil having sand, silt and clay as $67.3 \%, 18.1 \%$ and $14.6 \%$ showed the sandy -loam in texture. The different P-fractions (Al$\mathrm{P}, \mathrm{Fe}-\mathrm{P}, \mathrm{Re}-\mathrm{P}$, and Ca-P ) of soils were recorded at CRI (Crown Root Initiation), flowering and at harvest of wheat respectively.

\section{Table 1: Important physico-chemical prop- erties of soil}

\begin{tabular}{ll}
\hline Soil Properties & \multicolumn{1}{c}{ Values } \\
\hline $\mathrm{pH}$ & 5.6 \\
$\left.\mathrm{EC}(\mathrm{dSm})^{-1}\right)$ & 0.06 \\
Organic carbon $(\%)$ & 0.40 \\
Available-N $\left(\mathrm{kg} \mathrm{ha}^{-1}\right)$ & 126.34 \\
Available-P $\left(\mathrm{kg} \mathrm{ha}^{-1}\right)$ & 20.13 \\
Available-K $\left(\mathrm{kg} \mathrm{ha}^{-1}\right)$ & 133.28 \\
Sand $(\%)$ & 67.30 \\
Silt $(\%)$ & 18.10 \\
Clay $(\%)$ & 14.60 \\
\hline
\end{tabular}

It was observed that a general trend of minimum value was observed at $T_{1}$ (untreated control) while maximum at $\mathrm{T}_{9}[\mathrm{NK}$ as $\mathrm{RD}$ and $\mathrm{P}$ as $150 \%$ of $\mathrm{RD}$ ] for all the P-fractions at three (CRI, flowering and harvest) stages of wheat under two different tillage operations. The average Al-P in soil at CRI, flowering and at harvest stage of wheat was $22.58,33.82$ and 58.90 $\mathrm{kg} \mathrm{ha}^{-1}$ (Figure 1, 2 and 3) respectively under conventional tillage while that of $17.59,25.33$ and $36.62 \mathrm{~kg} \mathrm{ha}^{-1}$ (Figure 1, 2 and 3) under zero tillage of operation. However, the Fe-P in soil at CRI, flowering and at harvest stage of wheat was $173.55,194.13$ and $251.09 \mathrm{~kg} \mathrm{ha}^{-1}$ (Figure 1, 2 and 3) under conventional tillage while that as $105.93,148.59$ and $144.29 \mathrm{~kg} \mathrm{ha}^{-1}$ (Figure 1, 2 and 3) under zero tillage practice. Similarly, the reductant soluble-P $\left(\mathrm{kg} \mathrm{ha}^{-1}\right)$ in soil at CRI, flowering and at harvest of wheat was 28.74, 23.01 and $14.39 \mathrm{~kg} \mathrm{ha}^{-1}$ (Figure 1, 2 and 3 ) under conventional tillage while that of 24.40, 19.57 and $12.59 \mathrm{~kg} \mathrm{ha}^{-1}$ (Figure 1, 2 and 3) under zero tillage practice. Again, the Ca-P in soil at CRI, flowering and harvest of wheat was $355.91,296.73$ and $231.36 \mathrm{~kg} \mathrm{ha}^{-1}$ (Figure 1,2 and 3 ) under conventional tillage while that from $321.70,275.36$ and $197.01 \mathrm{~kg} \mathrm{ha}^{-1}$ (Figure 1, 2 and 3) respectively under zero tillage practice. While comparing the $\mathrm{P}$-fractions in soils at different stages of the crop growth (CRI, flowering and harvesting), it was observed that the content of $\mathrm{Ca}-\mathrm{P}>\mathrm{Fe}-\mathrm{P}>\mathrm{Re}-\mathrm{P}>$ $\mathrm{Al}-\mathrm{P}$ in soil at the CRI stage (Figure 1) while 
the content of $\mathrm{Ca}-\mathrm{P}>\mathrm{Fe}-\mathrm{P}>\mathrm{Al}-\mathrm{P}>\mathrm{Re}-\mathrm{P}$ during flowering (Figure 2). Dominance of $\mathrm{Ca}-\mathrm{P}$ over other inorganic $-\mathrm{P}$ forms supported the contention that the soils were of recent alluvium of north eastern rivers (Mondal et al., 2007). It is further to mention that the availability of $\mathrm{P}$ both from $\mathrm{Ca}-\mathrm{P}$ and $\mathrm{Al}-\mathrm{P}$ is a $\mathrm{pH}-$ controlled process. It is worth mentioning that Al-system is more stable at low $\mathrm{pH}$, where, $\mathrm{Ca}-$ system is unstable and vice versa. Hence,

Table 2. Effect of forms of phosphorus on grain yield of wheat at harvest

\begin{tabular}{|c|c|c|}
\hline Conventional Tillage & $\begin{array}{l}\text { Contribution } \\
\left(R^{2} \times 100\right)\end{array}$ & $\Delta \mathbf{R}^{2}$ \\
\hline$Y_{1}=-0.469+0.072 X_{1}$ & 63.58 & - \\
\hline $\mathrm{Y}_{1}=21.307+0.185 \mathrm{X}_{1^{-}}$ & \multirow{2}{*}{77.24} & 13.6 \\
\hline $0.113 \mathrm{X}_{2}$ & & 6 \\
\hline $\begin{array}{l}Y_{1}=23.332+0.129 X_{1^{-}} \\
0.0116 X_{2}+0.121 X_{3}\end{array}$ & 84.70 & 7.46 \\
\hline$Y_{1}=25.023+0.088 X_{1^{-}}$ & \multirow{3}{*}{92.22} & \multirow{3}{*}{7.52} \\
\hline $0.131 \mathrm{X}_{2}+0.138 \mathrm{X}_{3}+0.019$ & & \\
\hline $\mathrm{X}_{4}$ & & \\
\hline \multicolumn{3}{|l|}{ Zero Tillage } \\
\hline$Y_{2}=-2.273+0.134 X_{1}$ & 48.37 & - \\
\hline $\begin{array}{l}Y_{2}=- \\
4.574+0.044 X_{1}+0.040 X_{2}\end{array}$ & 57.05 & 8.68 \\
\hline $\mathrm{Y}_{2}=19.222-0.0353 \mathrm{X}_{1^{-}}$ & \multirow{2}{*}{97.24} & 40.1 \\
\hline $0.096 \mathrm{X}_{2}+0.777 \mathrm{X}_{3}$ & & 9 \\
\hline $\mathrm{Y}_{2}=21.240-0.338 \mathrm{X}_{1}-$ & \multirow{3}{*}{97.45} & \multirow{3}{*}{0.21} \\
\hline $0.140 \mathrm{X}_{2}+0.816 \mathrm{X}_{3^{-}}$ & & \\
\hline $0.016 \mathrm{X}_{4}$ & & \\
\hline
\end{tabular}

$\mathrm{X}_{1}, \mathrm{X}_{2}, \mathrm{X}_{3}$ and $\mathrm{X}_{4}$ denote the Al-P, Fe-P, Re-P, Ca -P under conventional and zero tillage condition and $Y_{1}$ and $Y_{2}$ denote the grain yield under conventional and zero tillage condition respectively.

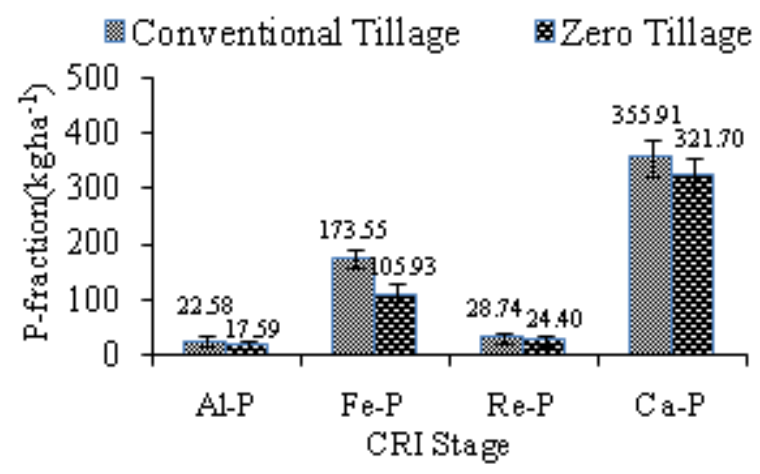

Figure 1: Effects of tillage operation in $\mathrm{P}$ fractions $\left(\mathrm{kg} \mathrm{ha}^{-1}\right)$ of soil at CRI stage of wheat. Error bars $(P<0.05)$ indicate the Standard Deviation (S.D.)

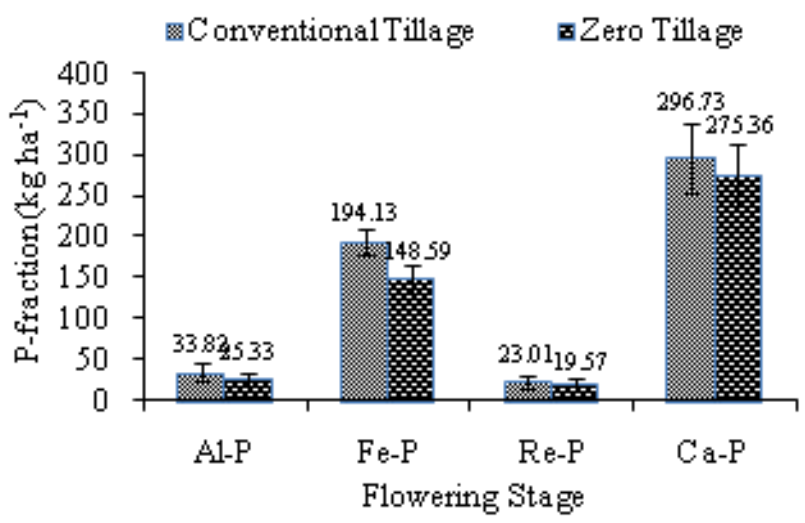

Figure 2: Effects of tillage operation in Pfractions $\left(\mathrm{kg} \mathrm{ha}^{-1}\right)$ of soil at flowering stage of wheat. Error bars $(\mathrm{P}<0.05)$ indicate the Standard Deviation (S.D.)

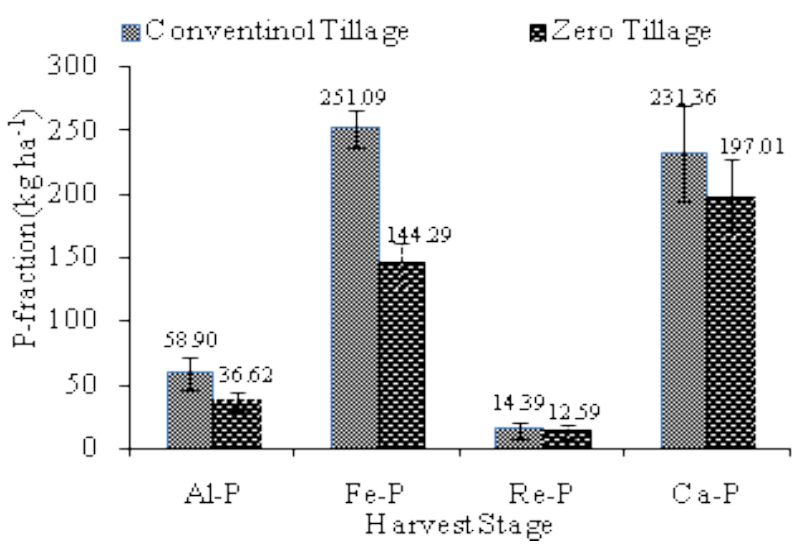

Figure 3: Effects of tillage operation in Pfractions $\left(\mathrm{kg} \mathrm{ha}^{-1}\right)$ of soil at harvest stage of harvest. Error bars $(P<0.05)$ indicate the Standard Deviation (S.D.) 
have higher value than all the other soil-P fractions. The quantity of fertilizer addition as well as stage of crop growth might have influenced the dynamic equilibrium between this $\mathrm{P}$ -form. However, the order for $\mathrm{Fe}-\mathrm{P}>\mathrm{Ca}-\mathrm{P}>\mathrm{Al}$ $\mathrm{P}>\mathrm{Re}-\mathrm{P}$ at harvest (Figure 3 ) under conventional and zero tillage of operations.

The average yield of wheat grain (Figure 4 ) showed relatively higher yield $\left(5.24 \mathrm{t} \mathrm{ha}^{-1}\right)$ at $\mathrm{T}_{9}$ under conventional tillage (CT) while the same was $4.66 \mathrm{t} \mathrm{ha}^{-1}$ under zero tillage (ZT) at the treatment $\mathrm{T}_{9}[\mathrm{~N}(100 \%)+\mathrm{K}(100 \%)+\mathrm{P}$ $(150 \%)$ ]. Significant difference in yield of wheat was observed under both the tillage operations over the control $\left(T_{1}\right)$ and among the other treatment combinations. The differences in yield between $\mathrm{CT}$ and ZT could have been caused by the differences in the nourishment of wheat plants during the growing period (Glubiak and Korzeniowska, 2010). It may so happen that wheat grown under CT was more prone to have biomass and yield for sufficient soil moisture condition than that at ZT. The nutrient movement from the soil to the plants during the initial two years of trial may be restricted under the $\mathrm{ZT}$ compared to the $\mathrm{CT}$ which has resulted the lower yield under ZT than under CT. However, the lower yield wheat under no tillage (NT) have been reported by De Vita et al. (2007) in a separate

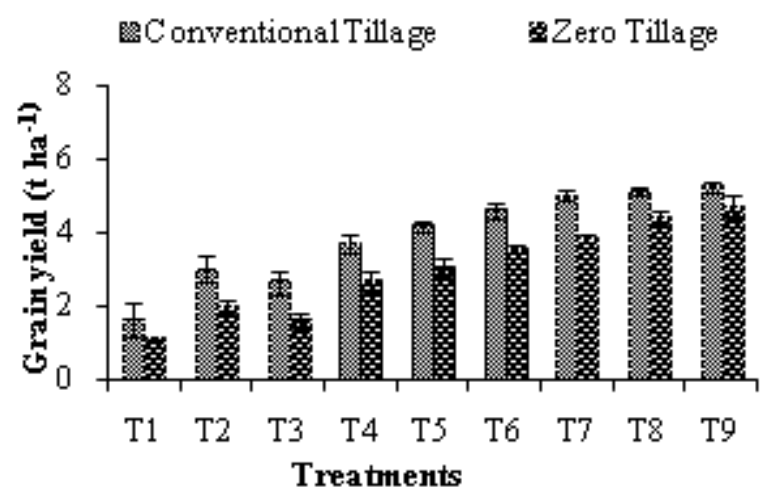

Figure 4: Effects of treatment on average yield $\left(\mathrm{t} \mathrm{ha}^{-1}\right)$ of wheat under conventional and zero tillage practices. Error bars $(\mathrm{P}<$ 0.05) indicate the Standard Deviation (S.D.) experiment elsewhere under the specific soilenvironment situation.

The variations and yield by all the contributing P-fractions was observed both under conventional and zero tillage of operations. The predictability between grain yield and $\mathrm{P}$ fractions varied from $7.46-13.66 \%$ (Table 2) during $2^{\text {nd }}$ year by inclusion of Fe-P, Re-P and $\mathrm{Ca}-\mathrm{P}$ with Al-P under conventional methods of practice while the same varied from $0.21-40.19 \%$ (Table 2) under zero tillage practice. Thus, from the stepwise regression equation, it was observed that Al-P was the dominant inorganic form of $\mathrm{P}$ in soil which contributed maximum to the available- $\mathrm{P}$ uptake and thus affecting the yield of the crop.

\section{CONCLUSIONS}

The acidic reaction in soil might have caused wide variations in native $\mathrm{P}$-fractions (Al-P, Fe -P, Re-P and Ca-P). The correlation of various inorganic -P fractions with yield of wheat showed the significant differences among the treatment combinations under the two different tillage operations. It was apparent that the soil-P management practices might have some contribution towards the performances of the given tillage operations.

\section{REFERENCE}

Black CA 1965 Methods of soil analysis. Part II, Agron. Ser. No. 9. American Society of Agronomy Inc. Madison, Wisconsin, U.S.A.

De Vita P, Di Paulo E, Fecondo G, Di Fonzo $\mathrm{N}$ and Pisante M 2007 No tillage and conventional tillage effects on durum wheat yield, grain quality and soil moisture content in Southern Italy. Soil and Tillage Res. 92: 69-78.

Glubiak SE and Korzeniowska J 2010 Yield of winter wheat grown under zero 
and conventional tillage on different soil types. Agronomy Res.8: 263-271.

Mondal GK, Pal SK and Roy A 2007 Phosphorus availability indices of soils under various land uses in Terai zone of West Bengal. J. of the Ind. Soc. of Soil Sci.55: 36-39.

Petersen GW and Corey RB 1966 A modified Chang and Jackson procedure for routine fractionation of inorganic soil phosphates. Soil Sci. Soc. of Am. J.30: 563565.

Slaton NA, CE Jr ,Wilson RJ, Norman S, Tamatungiro N and Frizzell DL 2002 Rice responses to phosphorus fertilizer application rate and timing on alkaline soils in Arkansas. J. of Agro. 94: 13931399.

Tarafdar JC, Yadav RS, Bareja M and Singh G 2006 Phosphorus fractionation under crops, trees and grasses. J. of the Ind. Soc. of Soil Sci. 54: 38-44. 